\title{
Residents Of The United States: A Study On Status Based On The Internal Revenue Code: Citizenship as a Defense to the "Subject to..." Clause of the Internal Revenue Code.
}

Larry M. López, (Email: lopezl@mscd.edu), Metropolitan State College of Denver

\begin{abstract}
This paper will focus on the meaning of the terms resident, United States and residence as they are used in the Internal Revenue Code, Title 26 United States Code (U.S.C.). The general meanings of these terms vary depending upon the purpose of the legislation. As will be shown, Congress has expressly defined their meaning in the Internal Revenue Code (hereafter, IRC) to the exclusion of all others. While several articles [1] have been written discussing the meaning Congress intended these terms for purposes of federal income taxation, no article, annotation or book has viewed the meaning of these terms from the perspective of the U.S. Constitution and how they have been interpreted using fundamental principles of statutory construction in court cases.
\end{abstract}

\section{Introduction}

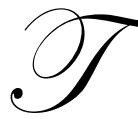

The meaning of the terms resident, United States, and residence may be evident, however, the inquiry of this paper was prompted by the increase, in recent years, of dozens of cases across the United States, where U.S. citizens who consider themselves putative taxpayers have challenged their federal income tax liability on the basis that they are nonresident aliens who have no income subject to federal income taxation. All of these cases are based on one of two contentions: a) Each of the individual States of the Union are separate and distinct foreign countries to each other as well as the United States (i.e., Washington, D.C., federal enclaves, U.S. possessions and territories), and therefore, individuals not born in these locations are aliens; and if not living in these areas they are nonresident, thus they are nonresident aliens to the United States; b) There are two types or classes of individuals denoted as citizens of the United States. In the original U.S. Constitution those individuals of African and Oriental descent did not qualify as a Citizen of a state or of the United States; and it was only by and through the 14th Amendment that these individuals acquired citizenship, which was intentionally different from that of the white citizens to whom the said amendment did not apply, and thus, all individuals of Anglo-Saxon origin are alien to this citizenship. Further, as only 14th Amendment citizens receive the benefits of the amendment, i.e., the protection of the United States government against infringement of their civil rights by any of the state governments, they are residents, and therefore, as the white citizens receive no protection from the 14th Amendment they are nonresidents. The 14th Amendment definition of citizen of the United States also appears in Treasury Regulation 1.1-1(c) and accordingly that is the intended meaning used in the IRC. However, as this definition does not apply to white citizens, therefore, in the terms of the IRC, they are nonresident aliens subject to federal income taxation only under the provisions of 26 U.S.C $\S 871$, and not $\S 1$. Regardless of the theory used, the federal courts at every level have unanimously rejected these arguments and all derivatives thereof [2]. 


\section{Judicial Construction Of Statutes}

In a general sense statutory construction is that branch of law dealing with the interpretation of laws enacted by a legislature. A judicial function required when a statute is invoked and different interpretations are in contention. It is the process, or the art, of determining the sense, real meaning, or proper explanation of obscure or ambiguous terms or provisions in a statute, Congressional Record, or oral argument and testimony, or the application of such subject to the statute in question, by reasoning in the light derived from extraneous connected circumstances of enactment or writings bearing upon the same or a connected matter, or by seeking and applying the probable aim and purpose of the provision [3].

All courts use principles of statutory construction to interpret the meanings of words used in statutes. The United States Supreme Court uses many sources to assist in the inter-interpretation of the constitution and the statutes enacted under its authority [4]. The concepts of law are conveyed and expressed in words. It is elementary when interpreting a law, a written or oral contract, etc., that the meaning and purpose of the words employed be clearly understood. For this reason it is a firmly established principle of statutory interpretation that the words in a statute, including revenue acts, should be interpreted where possible in their ordinary, everyday sense [5]. The starting point in every case involving the construction of a statute is the language itself [6] and if its meaning is plain it must be accepted without modification and enforced as written unless Congress has definitely indicated an intention that they shall be construed otherwise [7]. If the statutory language is clear, it is ordinarily conclusive [8]. However, if the language is ambiguous, then the courts may properly use the legislative history of the statute to reach a conclusion [9] for the intent of the lawmaker constitutes the law and that intent must be sought [10].

In the absence of a statutory definition, a court construing a statute will start with the assumption that the legislative purpose is expressed by the ordinary meaning of the words used, in light of the object and policy of the statute [11]. It is not, however, unusual for statutes to contain a definition of the terms used in them. Statutory definitions may appear either in separate sections, or in the body of substantive sections. It is commonly understood that such definitions establish meaning where the terms appear in that same act of in the case of general interpretative statutes, the definition extends to as much legislation as the general act itself designates. As a rule a definition that declares what a term means is binding upon the court. In order to avoid repugnance with other parts of the act and conflict with legislative intent, the words may be restricted or expanded by the subject matter. A term whose statutory definition declares what it includes is more susceptible to extension of meaning by construction than where the definition declares what a term means [12]. The word includes is usually a term of enlargement, and not of limitation. It therefore, conveys the conclusion that there are other items includable, though not specifically enumerated. A definition which declares what a term means, on the other hand, excludes any meaning that is not stated [13]. Statutory definitions of terms used in a statute prevail over colloquial meanings [14]. The commonly accepted or dictionary meaning of a term used in a statute is not a substitute for the definition found in the statute itself [15]. Nor may a word be imported into a statute in order to change its meaning [16].

The above-mentioned principles of construction, and all others, apply with equal force to interpretation of words or phrases used in the U.S. Constitution. It is elementary that the Constitution is the supreme law of the land [17] and that all statutes enacted by Congress must strictly comply with the language specified by the constitution [4]. An excellent illustration of this point occurred in Eisner v. Macomber [18] where the U.S. Supreme Court was called upon to interpret the meaning of income in the 16th Amendment, the Court stated:

"In order, therefore, that the clauses cited from Article I of the Constitution may have proper force and effect, save only as modified by the Amendment, and that the latter also may have proper effect, it becomes essential to distinguish between what is and what is not "income," as the term is there used; and to apply the distinction, as cases arise, according to truth and substance, without regard to form. Congress cannot by any definition it may adopt conclude the matter, since it cannot be legislation alter the Constitution, from which alone it derives its power to legislate, and within whose limitations alone that power can be lawfully exercised."

For this very reason Congress is not at liberty to define the meaning of United States or resident outside of the intended meaning of those terms in the Constitution and its Amendments. A fortiori, neither may a litigant who 
wishes to impute a meaning of these terms at variance with their ordinary meaning as expressed by the Law of the Land or on the face of any statute made in pursuance thereof.

\section{United States Constitution, The $14^{\text {th }}$ Amendment, The Internal Revenue Code And The Immigration And Naturalization Act}

In the body of the Constitution appear several references to the term inhabitant Art. I, § 2, clause 2 (No Person shall be a Representative who shall not have ... .been seven Years a Citizen of the United States, and who shall not, when elected, be an Inhabitant of the State in which he shall be chosen.); Art. I, § 3, clause 3 (No Person shall be a Senator who shall not have . . been nine Years a Citizen of the United States, and who shall not, when elected, be an Inhabitant of the State in which he shall be chosen.); Art. II, § 1, clause 3 (The Electors shall . . vote by Ballot for two Persons, of whom one at least shall not be an Inhabitant of the same State with themselves.). Only one reference is made to resident Article II, § 1, clause 5, which reads: "No person except a natural born Citizen, or a Citizen of the United States, at the time of the Adoption of this Constitution, shall be eligible to the Office of President; neither shall any Person be eligible to that Office who shall not have attained to the Age of thirty-five Years, and been fourteen Years a Resident within the United States." See also these same references for Citizen of the United States. In construing the meaning of these terms: "Where words are employed in a statute which had at the time a well-known meaning at common law or in the laws of this country, those words are presumed to have been used in that sense unless the context compels to the contrary." [19] The context in which the terms Inhabitant and Resident are used very clearly means an individual who lives within the territorial borders of the United States. The term Citizen simply means someone born in this country (a native), or an alien who has been adopted as a native citizen under the laws of the United States.

The original Constitution contained no definition of the term citizen of the United States. This was the case until the 14th Amendment became part of the organic law of the United States [20]. Section 1, clause 1 of the Amendment reads: "All persons born or naturalized in the United States, and subject to the jurisdiction thereof, are citizens of the United States and of the State wherein they reside." The Supreme Court has held that the primary purpose of the 14th Amendment was to provide citizenship for those of African descent [21]. The Court drew a distinction between citizens of a State and citizens of the United States only stating that the former were ipso facto citizens of the United States and already possessed of dual citizenship and were therefore not affected by the Amendment. The latter, by operation of the Amendment, were also included in the same citizenship with its attendant privileges and immunities. In other words, if you are born in the United States and owe no allegiance to a foreign power, you are a citizen of the United States; no longer was race a factor in determining such citizenship.

Even though the Constitution contained no definition of citizen prior to the 14th Amendment, Congress is expressly authorized by Article I, § 8, clause 4, "To establish an uniform Rule of Naturalization, ..." This is an exclusive power; no State has the power to constitute a foreign subject a citizen of the United States [22]. Naturalization has been defined by the Supreme Court as "the act of adopting a foreigner, and clothing him with the privileges of a native citizen." [23] Qualifications on citizenship are determined by the Immigration and Naturalization Laws of the United States and it is not regulated by the provisions of the Internal Revenue Code [24]. The Immigration and Naturalization Act defines alien as any person not a citizen or national of the United States [25] and defines national of the United States as (A) a citizen of the United States, or (B) a person who, though not a citizen of the United States owes permanent allegiance to the United States [26]. In this Act the term United States except as otherwise specifically provided, when used in a geographic sense, means the continental United States, Alaska, Hawaii, Puerto Rico, Guam, and the Virgin Islands of the United States [27].

The term citizen of United States is defined in the Act at 8 U.S.C. $\S 1401$, where Congress has categorized citizens into seven categories: the first merely tracks the language of the first sentence of $\S 1$ of the Fourteenth Amendment. But there are six other categories of citizens by birth [28]. Subsection (7) citizens must satisfy the condition subsequent of five years continuous residence within the United States between the ages of fourteen and twenty-eight, a requirement held to be constitutional [29], which means in effect that for constitutional purposes according to the prevailing interpretation there is a difference between persons born or naturalized in, that is, within, the United States and persons born outside the confines [borders] of the United States who are statutorily made 
citizens [30]. As defined in the Act the term residence means the place of general abode; the place of general abode of a person means his principal, actual dwelling place in fact, without regard to intent [31].

In view of the whole purpose intended by the Act it seems rather clear that the United States means the whole of the territorial borders comprised of the several States of the Union and the territories and possessions of the United States. To the exclusion of all other meanings, Congress has expressly defined the term United States to mean a specific region of land, it has not defined the term in a jurisdictional or political sense under the 14th Amendment. The term residence in the Act, the term resides in the 14th Amendment and the term resident in the Constitution simply refer to the physical presence of an individual within a specific region of land, in this case the United States. The term citizen of the United States as defined in the 14th Amendment and the Act, and as used in the Constitution primarily means an individual born within the territorial borders of the United States. Their meaning is common and ordinary.

\section{Meaning of United States in the Internal Revenue Code.}

History conclusively establishes at the time the Nation identified as the United States of America came into being, it was comprised of the original 13 colonies which became states. Over time the number of states admitted to the Union steadily increased. Today the States of the Union number 50. It is clear that the Founders of this Nation intended to create not only a nation identified as the United States but also a government thereof for the purposes of representing the States of the Union in the International community as well as regulating interests common to all of the States, e.g., "To Regulate Commerce with foreign Nations, and among the several States, and with the Indian Tribes; [and] To establish an uniform Rule of Naturalization." Article I, § 8, clauses 3 and 4. At its inception as well as today, the terms United States or United States of America as used in the U.S. Constitution, simply mean the States collectively as a whole in a general sense, territory comprised of the individual States collectively as a whole, and the governing political body representing the States collectively in the World community. The U.S. Supreme Court has clearly pronounced and underscored these understandings:

"The term "United States" may be used in any one of several senses. It may be merely the name of a sovereign occupying the position analogous to that of other sovereigns in the family of nations. It may designate the territory over which the sovereignty of the United States extends, [*672] or it may be the collective name of the states which are united by and under the Constitution." [32]

IRC § 7701(a)(9) defines United States "when used in a geographic sense includes only the States and the District of Columbia." This definition is one of limitation as the word 'only' qualifies 'includes.'

In view of the whole purpose intended by the statute it seems rather clear that the United States means the whole of the territorial borders comprised of the several States of the Union and the District of Columbia. This is in keeping with the common and ordinary use of the term in the Constitution respecting citizenship, inhabitant and resident. To the exclusion of all other meanings, the Congress has expressly defined the term United States to mean a specific region of land, it has not defined the term in a jurisdictional or political sense under the 14th Amendment. Moreover, while Congress has defined United States to mean other areas for purposes of specific statutes, see, for example, 26 U.S.C. § 638(1) (the term "United States" when used in a geographical sense includes the seabed and subsoil of those submarine areas which are adjacent to the territorial waters of the United States ..."), and 26 U.S.C. $\S 3121(\mathrm{e})(2)$ (The term "United States" when used in a geographical sense, includes the Commonwealth of Puerto Rico, the Virgin Islands, Guam and American Samoa."), these other definitions in the IRC only apply to the subtitle, chapter, section or sub-section intended and are not controlling in other statutes.

\section{Meaning of Resident in the Internal Revenue Code and Treasury Regulations.}

The word resident has many meanings in the law, largely determined by the statutory context in which it is used [33]. Under the provisions of the Uniform Commercial Code of New York, residence means living in a particular locality and requires bodily presence as inhabitant in a given place [34]. Under the provisions of the Bankruptcy Code, residence simply requires bodily presence as an inhabitant in a given place [35]. As used in the 
IRC and Treasury Regulations the term "resident" of the United States is a legally synonymous with a "resident" alien individual Treas. Reg. 1.1-1(b). The nexus is the actual presence within the United States. With the Deficit Reduction Act of 1984, Congress enacted IRC $\S 7701$ (b) [36], a definition of the term resident alien applicable for income tax purposes [37] and it became effective January 1, 1985. This definition applies only for purposes of calculating an alien's U.S. income tax liability [38]

When the principles of statutory construction and the plain meaning of the terms residence and resident (alien) become redundant and similar in their meaning. Which consistently states that an alien individual physically or actually present in the United States for a specified amount of days, is a resident of the United States for purposes of the income tax. The plain meaning of these terms is in keeping with the Constitution and Laws of the United States. Although the statutes and regulations are clear enough in their meaning, it is always wise to review how the Internal Revenue Service and the federal courts interpreted these terms.

\section{IRS Rulings and Other Case Law.}

A softbound volume entitled "Bulletin Index Digest System, Service 1 Income Tax" [39] contains a listing of all Internal Revenue Service Revenue Rulings issued under each Treasury Regulation. The oldest dates back to 1959 and the most recent was issued in 1981. All of these Rev. Rulings pertain to determining residence of alien individuals and consistently state the same language. As an example, the issue in Rev. Ruling 81-70, 1981-1 C.B. 389, concerned the presumption of nonresidence provided in Treas. Reg. 1.871-4(b) of an alien individual illegally present in the United States. The Service stated: "Thus, the presumption can be overcome by proof of acts and statements showing (1) a definite intention to reside in the United States permanently or (2) a stay of an extended nature. See, e.g., Marsman v. Commissioner, 205 F.2d 335 (4th Cir. 1953); Rev. Rul. 64-149, 1964-1 (Part I) C.B. 233, 235." Id. at 390. The Service concluded that the presumption of nonresidence was overcame by the alien's definite intention to reside in the United States on more than a temporary basis as he was here for almost 8 years and performed service to and involvement in his community. The Service stated that under the circumstances the alien was a resident of the United States for federal income tax purposes.

The federal courts have consistently interpreted these terms in the same manner as has the Service. The case cited above in Rev. Ruling 81-70 was a proceeding upon a petition to review a decision of the U.S. Tax Court, 18 T.C. 1, which held that the petitioner, a Philippine citizen, was taxable on all undistributed income of a Philippine corporation for the entire year of 1940. The petitioner had been admitted to the United States on September 22, 1940 for a temporary period of ten months and who remained in the United States continuously from that date until 1945, was held to be a resident of the United States for income tax purposes under Treas. Reg. $111 \S 29.211-2$ even though she intended to return to the Philippines after the danger of war in the Orient had subsided. Id. at 338.

In Commissioner of Internal Revenue v. Patino the issue before the 4th Circuit Court of Appeals concerned the residence of Cristina deBourbon Patino a national of Spain who in 1940 left Spain for the United States to avoid the German invasion. She was present in the United States from October, 1940 through 1945 occupying an apartment in the Plaza Hotel in New York. The court held that: "In passing on this question we are aided by the definition of the term "residence" in Regulation 111 \& 29.211-2 and by the rules of evidence to be used in determining a question of residence in the United States set out in Regulation $111 \S 29.211-4$. . . and have been approved as a correct exposition of the law by the decisions of this and other courts [40]. Under the rules there set out it appears that one who lives in the United States and has no definite intention as to his length of stay is a resident; . . . Certainly this language is descriptive of the taxpayer's sojourn in the United States. ... Her long stay in New York from year to year despite her separation from her husband and her compete legal and financial freedom to go to other lands untroubled by the world conflict, proved beyond any reasonable doubt not only her physical presence in the United States but a deliberate intention to reside in this country so long as it might suit her convenience."

The revenue rulings and cases discussed above and those cited in the footnotes thoroughly and adequately discuss how residence of an alien individual is determined. In every case (and many more not cited) the courts and the Service have unanimously and overwhelmingly held that mere presence in the United States is sufficient to 
establish residence and once established that individual is a resident of the United States for purposes of the income tax. A holding to the contrary would be at variance with the Constitution and Immigration Laws of the United States.

\section{Conclusion}

The terms residence and resident of the United States in the Internal Revenue Code and the Treasury Regulations promulgated thereunder have been consistently interpreted by the Internal Revenue Service, the Tax Court, and all federal courts. The term resident simply means an alien physically and actually present for a specified number of days within the territorial borders of the United States. The term residence simply means an actual dwelling place or location within the United States. The same is true of the term United States as it is used in the Internal Revenue Code, the Treasury Regulations, and the Constitution and Immigration Laws of the United States. In all sources referenced and discussed in this article the term United States simply means the whole of the territorial borders comprised of the several States of the Union and the District of Columbia, and in some statutes the U.S. possessions and territories. There is nothing mystical or deceitful about the meanings of these words. They have common and ordinary meanings and usage as made evident by the dearth of law review articles, annotations, books, and the sheer number of federal court cases and revenue rulings.

There are some pretty slick snake oil salesmen out in the community that will be willing, for a fee, of course, to lead a taxpayer into the belief that if the taxpayer is a resident of a State then they are not residents of the United States, and thus are not "subject to" the Internal Revenue Code and therefore do not have to file their 1040 any longer. These theories cycle into popularity every five to eight years. The motives for believing such theories are as various as the individuals who "buy into" the belief. The most destructive prosecutorial (yes, these do end up in criminal charges) evidence is the complete absence of a State Tax Return. It is philosophically indefensible to say that you are a State citizen, and therefore are not required to file a Federal income tax return, and then fail to file the State income tax return.

\section{References}

1. New York State Bar Association Tax Section Committee on U.S. Activities of Foreign Taxpayers, Report on the Definition of "Resident" in Section 451 of the Tax Reform Bill of 1983 (H.R. 4170, the "Bill"), 10 Inter-national Tax Journal 173 (March 1984); Langer, Congress Creates a Modern-Day Centaur-The Halfresident Alien, 10 International Tax Journal 173 (May 1984); Heizer and Braun, Working With the New Definition of "Income Tax Resident," 11 International Tax Journal 109 (Spring 1985); and Curtis, U.S.-West Germany Tax Treaty and the Section 7701(b)(1) Definition of "Resident Alien," 13 International Tax Journal 53 (Winter 1987)

2. $\quad$ Pekrul v. C.I.R., TCM 1992-455, 64 TCM (CCH) 453; Sharon v. C.I.R., 952 F.2d 1400 (9th Cir. 1992, unpublished); Fannon v. I.R.S. 958 F.2d 376 (9th Cir. 1992, unpublished); U.S. v. Plemons, 956 F.2d 273 (7th Cir. 1992, unpublished); McKinley v. U.S., 70 A.F.T.R.2d, 92-5805, 92-2 USTC II 50,509 (S.D. Ohio, E.D. 1992); Epperly v. U.S. et al, 1992 WL 349012 (9th Cir. 1992, unpublished); U.S. v Sloan, 939 F.2d 499 (7th Cir. 1991); Lonsdale v. U.S., 919 F.2d 1440 (10th Cir. 1990); U.S. v. Studley, 783 F.2d 934 (9th Cir. 1986).

3. $\quad$ Black's Law Dictionary, 5th Ed. (1979), pages 283 and 1266.

4. [One source of intrinsic aid used by the U.S. Supreme Court is: Singer, Statutes and Statutory Construction, (5 $5^{\text {th }}$ Ed., 1992), KF425.S254.

5. United States Supreme Court Digest, Lawyers Ed., § 165 generally. Hanover Bank v. Commissioner, 369 U.S. 672, 82 S.Ct. 1080, 8 L.Ed2d. 187; and Commissioner v. Brown, 380 U.S. 563, 85 S.Ct. 1162, 14 L.Ed.2d 75 .

6. U.S. S.Ct. Digest, Lawyers Ed., $\S \S 164$ and 165, generally. Moskal v. U.S., 111 S.Ct. 462, 112 L.Ed.2d 449; CBS, Inc. v. Federal Communications Com., 453 U.S. 367, 101 S.Ct. 2813, 69 L.Ed.2d 706; and Dewey v. U.S. 178 U.S. 510, 20 S.Ct. 981, 44 L.Ed.1170. 
7. U.S.S.Ct. Digest, L.Ed., $§ § 164$ and 165. Avery v. Commissioner, 292 U.S. 210, 54 S.Ct. 674, 78 L.Ed. 1216; U.S. v. Standard Brewery, 251 U.S. 210, 40 S.Ct. 139, 64 L.Ed. 229; and Thompson v. U.S., 246 U.S. 547, 38 S.Ct. 349, 62 L.Ed. 876.

8. U.S.S.Ct. Digest, L.Ed., § 164. U.S. v. Clark, 454 U.S. 555, 102 S.Ct. 805, 70 L.Ed.2d 768; and American Bank \& Trust Co. v. Dallas County, 463 U.S. 855, 103 S.Ct. 3369, 77 L.Ed.2d 1072.

9. $\quad$ U.S. v. Public Utilities Com., 345 U.S. 295, 73 S.Ct. 706, 97 L.Ed. 1020.

10. U.S.S.Ct. Digest, L.Ed. § 91. Whitney v. Wyman, 101 U.S. 392, 25 L.Ed. 1050; and Ricketts, 297 U.S. 373, 56 S.Ct. 507, 80 L.Ed. 724.

11. Mississippi Band of Choctaw Indians v. Holyfield, 490 U.S. 30, 109 S.Ct. 1597, 104 L.Ed.2d 29 (1989).

12. Internal Revenue Code (Title 26, United States Code) § 7701(a)(1) defines person as an individual, a trust, estate, partnership, association, company or corporation. Treasury Regulation 301.7701-1 through 301.7701-4 further clarifies the meaning of these entities and 301.7701-5 defines domestic, foreign, resident and nonresident persons. See also, 26 U.S.C. § 7701(a)(31) for definition of foreign estate or trust.

13. Text taken from, Singer, Statutes and Statutory Construction, 5th Ed., § 47.07. Definition Provisions. pages 151-52 and footnotes cited therein. See, Colautti v. Franklin, 439 U.S. 379, 99 S.Ct. 675, 58 L.Ed.2d 596, 607; and Meese v. Keene, 481 U.S. 465, 107 S.Ct. 1862, 95 L.Ed.2d 415.

14. Western Union Telegraph Co. v. Lenroot, 323 U.S. 4990, 65 S.Ct. 335, 89 L.Ed. 414.

15. $\quad$ Fox v. Standard Oil Co., 294 U.S. 87, 55 S.Ct. 333, 79 L.Ed. 780.

16. $\quad$ Newhall v. Sanger, 92 U.S. 761, 23 L.Ed 769.

17. Article VI, clause 2 states: "This Constitution, and the Laws of the United States which shall be made in Pursuance thereof; and all Treaties made, or which shall be made, under the Authority of the United States, shall be the supreme Law of the Land; ..."

18. $\quad 252$ U.S. 189, 206-207, 64 L.Ed. 521, 528-29 (1919).

19. Lorillard, Div. of Loew's Theaters, Inc., v. Pons, 434 U.S. 575, 55 L.Ed.2d 40; and Case v. Los Angeles Products Co., 308 U.S. 106, 60 S.Ct. 1, 84 L.Ed. 110.

20. The Fourteenth Amendment was ratified on July 9, 1868.

21. The Slaughter-House Cases, 83 U.S. (16 Wall.) 36, 21 L.Ed. 394, 407-08 (1872).

22. Chirac v. Chirac, 2 Wheat. (15 U.S.) 259, 269 (1817); and U.S. v. Wong Kim Ark, 169 U.S. 649, 701 (1898).

23. Boyd v. Nebraska ex rel. Thayer, 143 U.S. 135, 162 (1892).

24. Immigration and Naturalization Act, 8 U.S.C. $\S \S 1101$ et seq. Act June 27, 1952, ch 477, Title IV, $\S 407$, 66 Stat. 281; 1 Stat. 103 (1790) (first naturalization act restricted naturalization to free white persons); and Act of July 14, 1870, § 7, 16 Stat. 254, 256 (expanded in 1870 so that persons of African nativity and descent entitled to be naturalized). See, also Treasury Regulation 1.1-1(c)(in defining citizen of the United States, reference is made to the Immigration and Naturalization Act, supra.)

$25 . \quad 8$ U.S.C. $\S 1101(\mathrm{a})(3)$.

26. 8 U.S.C. $\$ 1101(\mathrm{a})(22)$

27. 8 U.S.C. $\S 1101(\mathrm{a})(38)$.

28. These are: (2) a person born in the United States to a member of an Indian, Eskimo, Aleutina, or other aboriginal tribe, (3) a person born outside the United States of citizen parents one of whom has been resident in the United States, (4) a person born outside of the United States of one citizen parent who has been continuously resident in the United States for one year prior to the birth and of a parent who is a national but not a citizen, (5) a person born in an outlying possession of the United States of one citizen parent who has been continuously resident in the United States of an outlying possession for one year prior to the birth, (6) a person born of unknown parentage found in the United States while under the age of five unless prior to his twenty-first birthday he is shown not to have been born in the United States, and (7) a person born outside the United States of an alien parent and a citizen parent who has been resident in the United States for a period of ten years is a citizen, provided the person is to lose his citizenship unless he resides continuously in the United States for a period of 5 years between his fourteenth and twenty-eight birthdays. 29. Rogers v. Bellei, 401 U.S. 815, 91 S.Ct. 1060, 28 L.Ed2d 499 (1971).

30. See, e.g., Schneider v. Rusk, 377 U.S. 163 (1964). All text taken from: The Constitution of the United States of America, Analysis and Interpretation, (1972) KF4527.A2, Naturalization and Citizenship, Nature and Scope of Congress' Power, pages 283-85. 
31. 8 U.S.C. 1101(a)(33).

32. $\quad$ Hoover \& Allison Co. v. Evatt, 65 S.Ct. 870, 880, 324 U.S. 652, 89 L.Ed. 1252.

33. Arredondo v. Brockette, 648 F.2d 425, certiorari granted, Martinex v. Bynum, 457 U.S. 1131, 102 S.Ct. 2955, 73 L.Ed.2d 1347, affirmed 461 U.S. 321, 103 S.Ct. 1838, 75 L.Ed.2d 879.

34. In re Knapp, 575 F.2d 341 (2nd Cir. 1978).

35. Wolinsky v. Bradford National Bank, 34 Bankruptcy Rptr. 702 (D.C.Vt. 1983).

36. Section 7701(b)(1) states in pertinent part:

(A) Resident alien. An alien individual shall be treated as a resident of the United States with respect to any calendar year if (and only if) such individual meets the requirements of clause (i), (ii), or (iii):

(i) Lawfully admitted for permanent residence. Such individual is a lawful permanent resident of the United States at any time during such calendar year.

(ii) Substantial presence test. Such individual meets the substantial presence test of paragraph (3).

(iii) First year election. Such individual makes the election provided in paragraph (4).

Subsection 7701(b)(3). Substantial presence test, states in pertinent part:

(A) In general. Except as otherwise provided in this paragraph, an individual meets the substantial presence test of this paragraph with respect to any calendar year ... if-

(i) such individual was present in the United States on at least 31 days during the calendar year, and

(ii) the sum of the number of days on which such individual was present in the United States during the current year and the 2 preceding calendar years . . . equals or exceeds 183 days.

Subsection 7701(b)(4). First-year election, states in pertinent part:

(A) An alien individual shall be deemed to meet the requirements of this subparagraph if such individual-

(iii) is a resident of the United States under clause (ii) of this paragraph (1)(A) with respect to the calendar year immediately following the election year, and

(iv) is both-

(I) present in the United States for a period of at least 31 consecutive days in the election year, and

(II) present in the United States during the period beginning with the first day of such 31-day period and ending with the last day of the election year

Subsection 7701(b)(6). Lawful permanent resident, states in pertinent part:

For purpose of this subsection, an individual is a lawful permanent resident of the United States at any time if-

(A) such individual has the status of having been lawfully accorded the privilege of residing permanently in the United States as an immigrant in accordance with the immigration laws, and...

Subsection 7701(b)(7). Presence in the United States, states in pertinent part:

(A) In general. Except as provided in subparagraph (B) or (C), an individual shall be treated as present in the United States on any day if such individual is physically present in the United States at any time during such day.

37. Deficit Reduction Act of 1984 (DEFRA), Pub.L. No. 98-369, section 138(a).

38. H.R. Rep. No. 432 (Part II), 98th Congr.2d Sess. at 1525 (1984). See, article by Heizer and Braun, Working With the New Definition of "Income Tax Resident", supra at note 3, page 112.

39. Bulletin Index Digest System, Service 1 Income Tax, Basic Volume 1953-1988, pages 38 and 39, lists all Revenue Rulings issued under Treas. Regs 1.861 through 1.898. KF6301.A5551.

40. Cited cases are: Myers v. Commissioner, 180 F.2d 969 (4th Cir. 1950); and Swenson v. Thomas, 164 F.2d 783 (5th Cir. 1947). See also, Commissioner v. Swent, 155 F.2d 513 (4th Cir. 1946); Commissioner v. Nubar, 185 F.2d 584 (4th Cir.); and Downs v. Commissioner, 166 F.2d 504 (9th Cir. 1948). See also cases cited in each of these. 